\title{
Studies on Effect of Chemical Preservatives on Keeping Quality of Kesar Mango Pulp
}

\author{
Sakhale $\mathrm{BK}^{1 *}$, Pawar $\mathrm{VN}^{2}$ and Ranveer $\mathrm{RC}^{3}$ \\ ${ }^{1}$ Department of Chemical Technology, Food Technology Division, Dr.Babasaheb Ambedkar Marathwada University, Aurangabad-431004 \\ ${ }^{2}$ Faculty of Food Technology, M.A.U, Parbhani \\ ${ }^{3}$ Department of Food Science and Technology, Shivaji University, Kolhapur, M.S., India
}

\begin{abstract}
The attempts are made in the present investigation to know the effect of various chemical preservatives on shelf life of Kesar mango pulp. The uniformly ripened Kesar mango pulp was pasteurized at $82 \pm 2{ }^{\circ} \mathrm{C}$ temperature for 30 minutes and acidity was adjusted to $1 \%$ with citric acid and preserved by chemical additives such as sodium benzoate, potassium meta-bisulphite (KMS) and potassium sorbet each at $0.2 \%$ and the KMS and sodium benzoate each at $0.066 \%$ in equal proportion. The pulp was stored at ambient temperature for three months and assessed for microbial and sensory qualities. The experiment was carried out in Completely Randomized Design (CRD) with five treatments. It was observed that the treatment in which pulp preserved with $0.2 \%$ KMS and stored in glass bottles scored maximum for overall acceptability and had negligible microbial count. This treatment was found statistically significant over the rest of treatments. It was further observed that the pulp was safe without spoilage up to 90 days.
\end{abstract}

Keywords: Mango, Pulp, Chemical preservatives, Sensory qualities, Storage, Shelf life

\section{Introduction}

Mango (Mangifera indica L.) is the most important fruit crop in tropical and sub-tropical regions of the world. Mango fruit is considered to be one of the best fruits in the world market because of its excellent flavor, attractive fragrance, beautiful color, delicious taste and health giving properties [1]. The pulp obtained from mango is increasingly used in beverage, dairy and confectionery industries, where fruit purees and concentrates are the major intermediates. Generally, partially processed mango, as an industrial viable raw material available round the year is mango juice as a base for the production of nectar and other beverages. Accordingly, the world's total export volume of mango juice and pulp increased between 1999 and 2003 by $179 \%$ and $49 \%$ to 11,848 tons and 9510 tons, respectively, against the world production that has increased by $13 \%$ and $17 \%$, since 1999 to 151,998 tons of mango juice and 925,263 tons of mango pulp in 2004 [2]. Indian export of fresh mango and mango pulp was 79060.88 MTS of worth Rs.141.94 crore and 156835.51 MTS of Rs.505.83 crore in 2006-07 respectively [3]. Mango pulp as a source of major and minor nutrients has not only justified its nutritional status but also recognized as nutraceutical on the basis of presence of carotene as an antioxidant. Mangoes with higher initial concentration of $B$-carotene are found helpful for preventing the cancer [4].

The mango pulp is highly perishable in nature due to high moisture content hence, pulp is having shortest shelf life. Therefore, the efforts have been made in the present investigation in order to improve the shelf life of mango pulp by using the various safe preservatives and with their optimum concentrations.

\section{Materials and Methods}

\section{Preparation of mango pulp}

Uniformly ripened mangoes of $\mathrm{Cv}$. Kesar were procured from fruit market of Aurangabad city. The fruits after washing, peeling and coring were subjected to slicing and feasible for macerating in an electric blender to get homogeneous pulp. Then pulp was pasteurized in a water bath at a temperature of $82 \pm 2^{\circ} \mathrm{C}$ for $30 \mathrm{~min}$ to reduce the microbial load. The acidity was adjusted to $1.0 \%$ by addition of citric acid of commercial grade. The process flow chart for preparation of mango pulp is given in Figure 1.

\section{Storage treatments of mango pulp}

The pasteurized mango pulp was subjected to different predecided treatments and packed in $500 \mathrm{ml}$ capacity glass bottles. The following treatments were finalized on the basis of efficacy of chemical preservatives. $\mathrm{T}_{0}=$ Control (without any chemical preservatives), $\mathrm{T}_{1}=$ $0.2 \%$ sodium benzoate, $\mathrm{T}_{2}=0.2 \%$ potassium meta-bisulphite $(\mathrm{KMS}), \mathrm{T}_{3}$ $=0.2 \%$ potassium sorbet, $\mathrm{T}_{4}=0.066 \%$ each of $\mathrm{KMS}+$ Sodium benzoate.

The treated mango pulp was stored for a period of 3 months at ambient temperature $\left(27-35^{\circ} \mathrm{C}\right)$. The pulp was assessed for microbial and sensory attributes at an interval of 15 days for a total storage period of 90 days.

\section{Microbial and organoleptic evaluation of mango pulp}

Total bacterial count (TBC): The pulp samples were analyzed for microbiological quality by considering the total plate count as evaluation index as described [5].

Sensory evaluation: Ready to serve mango beverages were prepared by using pulp as quality beverage (selected treatments) and evaluated by a panel of 11 semi trained judges for sensorial quality characteristics on a 9 point Hedonic scale like color, flavor and over all acceptability as described [6].

Statistical analyses: The data generated during triplicate experimentation were recorded and statistically analyzed on standard software using standard procedure for analysis of completely randomized design (CRD). The treatment means, their standard errors

*Corresponding author: Sakhale BK, Food Technology Division, Department of Chemical Technology, Dr. Babasaheb Ambedkar Marathwada University, Aurangabad-431004; Email: bksakhale@gmail.com

Received March 12, 2012; Published July 25, 2012

Citation: Sakhale BK, Pawar VN, Ranveer RC (2012) Studies on Effect of Chemical Preservatives on Keeping Quality of Kesar Mango Pulp. 1: 184. doi:10.4172/ scientificreports. 184

Copyright: (c) 2012 Sakhale BK, et al. This is an open-access article distributed under the terms of the Creative Commons Attribution License, which permits unrestricted use, distribution, and reproduction in any medium, provided the original author and source are credited. 
Citation: Sakhale BK, Pawar VN, Ranveer RC (2012) Studies on Effect of Chemical Preservatives on Keeping Quality of Kesar Mango Pulp. 1: 184 doi:10.4172/scientificreports.184

Page 2 of 3

Mango fruits (uniform ripened without blemishes)

Washed with chlorinated water and surface dried

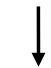

Peeled and destoned

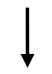

Extracted pulp

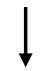

Pasteurized at $82 \pm 2^{0} \mathrm{C}$ for $30 \mathrm{~min}$

$$
\downarrow
$$

Chemical preservative added (KMS @ 700 mg/kg of pulp)

Filled the pulp in pre-sterilized glass bottles ( $500 \mathrm{ml}$ capacity)

Cooled and labeled

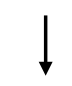

Stored at a cool and dry place

Figure 1: Process flow chart for extraction of mango pulp.

(SE) and critical differences (CD) at 5\% level of significance were worked out for comparison of treatments [7]. Further, confidence intervals were also worked out.

\section{Results and Discussion}

\section{Total bacterial count (TBC)}

The data on total bacterial count of mango pulp presented in Table 1 indicate that there was significant increase in TBC (8.0-390 $\mathrm{cfu} / \mathrm{g}$ ) of mango pulp during storage without addition of any chemical preservatives. The pulp with KMS alone as chemical preservative or in combination thereof (potassium sorbet and sodium benzoate) reported TBC values at par followed by mango pulp preserved with sodium benzoate and potassium sorbet notifying TBC values significantly more as compared to former and also at par amongst themselves $\left(\mathrm{T}_{1}-89, \mathrm{~T}_{3}-88 \mathrm{cfu} / \mathrm{g}\right)$. On the basis of TBC count at the end of storage period, it could be concluded that Kesar mango pulp may be stored without alterations in nutritional parameters by using $0.2 \% \mathrm{KMS}$ as a chemical preservative. The results recorded in this investigation on microbial quality of mango pulp are in agreement with the findings reported $[8,9]$.

\section{Organoleptic evaluation}

The mango pulp treated with specified treatments and stored in

\begin{tabular}{|c|c|c|c|c|c|c|c|}
\hline Treatments & \multicolumn{7}{|c|}{ Storage interval (days) } \\
\hline & Fresh & 15 & 30 & 45 & 60 & 75 & 90 \\
\hline $\mathrm{T}_{0}$ & 8 & 26 & 76 & 140 & 229 & 315 & 390 \\
\hline $\mathrm{T}_{1}$ & 8 & 15 & 32 & 48 & 57 & 71 & 89 \\
\hline $\mathrm{T}_{2}$ & 8 & 12 & 25 & 41 & 47 & 61 & 79 \\
\hline $\mathrm{T}_{3}$ & 8 & 13 & 31 & 51 & 57 & 69 & 88 \\
\hline $\mathrm{T}_{4}$ & 8 & 11 & 27 & 45 & 53 & 67 & 81 \\
\hline $\mathrm{SE}( \pm)$ & & 0.49 & 0.45 & 2.56 & 10.58 & 10.80 & 10.02 \\
\hline $\begin{array}{c}\mathrm{CD} \text { at 5\% } \\
\text { level of sig- } \\
\text { nificance }\end{array}$ & & 1.36 & 1.23 & 7.1 & 29.34 & 29.94 & 27.77 \\
\hline
\end{tabular}

*Each value is the average of four determinations.

$\mathrm{T}_{0}$ (Control), $\mathrm{T}_{1}\left(0.2 \%\right.$ sodium benzoate), $\mathrm{T}_{2}(0.2 \% \mathrm{KMS}), \mathrm{T}_{3}(0.2 \%$ potassium sorbet), $T_{4}$ (Combination)

Table 1: Effect of chemical preservatives on the total bacterial count (cfu/g) of mango pulp during storage*.

\begin{tabular}{|c|c|c|c|c|c|c|c|}
\hline Treatments & \multicolumn{7}{|c|}{ Storage interval (days) } \\
\hline & Fresh & 15 & 30 & 45 & 60 & 75 & 90 \\
\hline $\mathrm{T}_{0}$ & 9 & 7.9 & 6.4 & 4.7 & 4.8 & 3.3 & 1.9 \\
\hline $\mathrm{T}_{1}$ & 9 & 8.5 & 7.6 & 5.9 & 5.1 & 3.9 & 3.4 \\
\hline $\mathrm{T}_{2}$ & 9 & 8.6 & 8.3 & 7.8 & 7.5 & 6.9 & 6.5 \\
\hline $\mathrm{T}_{3}$ & 9 & 7.9 & 6.8 & 6.1 & 5.2 & 4.1 & 3.0 \\
\hline $\mathrm{T}_{4}$ & 9 & 8.3 & 8.1 & 7.8 & 7.3 & 6.8 & 5.7 \\
\hline $\mathrm{SE}( \pm$ ) & & 0.12 & 0.08 & 0.06 & 0.07 & 0.05 & 0.07 \\
\hline $\begin{array}{c}\text { CD at 5\% } \\
\text { level of sig- } \\
\text { nificance }\end{array}$ & & 0.34 & 0.23 & 0.17 & 0.19 & 0.14 & 0.19 \\
\hline
\end{tabular}

*Each value is the average of ten observations.

$\mathrm{T}_{0}$ (Control), $\mathrm{T}_{1}\left(0.2 \%\right.$ sodium benzoate), $\mathrm{T}_{2}(0.2 \% \mathrm{KMS}), \mathrm{T}_{3}(0.2 \%$ potassium sorbet), $\mathrm{T}_{4}$ (Combination)

Table 2: Effect of chemical preservatives on organoleptic score for color of mango pulp during storage.

glass containers for 90 days under ambient conditions was assessed for sensorial quality parameters at a frequent interval of time (15 days). The data on effect of various chemical treatments on quality parameters of mango pulp are presented in the respective tables.

Color: The organoleptic scores obtained for color are presented in Table 2. The sensory score for color of mango pulp without addition of chemical preservatives reported significantly decreased from 9 to 1.9 followed by pulp stored by using sodium benzoate and potassium sorbet during storage. The maximum score for color was observed in pulp with KMS ( $\left.\mathrm{T}_{2}-6.5\right)$ followed by $\mathrm{T}_{4}$ (combination), while minimum score was recorded in control sample $\mathrm{T}_{0}$ (1.9). The highest score of mango pulp with KMS as a chemical preservative is associated with more effective control of browning retaining original color, whereas the reduction in color scores might be due to superimposition of intermediate color developed due to Maillard reaction accelerated between reducing sugars and amino acids during storage.

Flavor: The data pertaining to sensorial qualities with respect to flavor are presented in Table 3. The sensory scores for flavor of mango pulp without addition of chemical preservatives were significantly decreased from 8.8 to 1.4 followed by pulp stored by using sodium benzoate and potassium sorbet during storage. The maximum score was recorded in pulp preserved with KMS $\left(\mathrm{T}_{2}-6.1\right)$ followed by $\mathrm{T}_{4}$ (Combination), whereas minimum score was recorded in the control sample without addition of chemical preservatives $\left(\mathrm{T}_{0}-1.4\right)$.

Overall acceptability: The sensory scores obtained for overall acceptability of mango pulp are presented in Table 4 . The score for overall acceptability of mango pulp without addition of chemical 
Citation: Sakhale BK, Pawar VN, Ranveer RC (2012) Studies on Effect of Chemical Preservatives on Keeping Quality of Kesar Mango Pulp. 1: 184. doi:10.4172/scientificreports.184

\begin{tabular}{|c|c|c|c|c|c|c|c|}
\hline Treatments & \multicolumn{7}{|c|}{ Storage interval (days) } \\
\hline & Fresh & 15 & 30 & 45 & 60 & 75 & 90 \\
\hline $\mathrm{T}_{0}$ & 8.8 & 6.9 & 4.9 & 3.7 & 2.1 & 1.8 & 1.4 \\
\hline $\mathrm{T}_{1}$ & 8.8 & 6.4 & 7.7 & 6.0 & 3.8 & 3.6 & 3.2 \\
\hline $\mathrm{T}_{2}$ & 8.8 & 8.9 & 8.1 & 7.9 & 7.6 & 6.9 & 6.1 \\
\hline $\mathrm{T}_{3}$ & 8.8 & 9.1 & 6.7 & 5.8 & 5.1 & 3.9 & 2.7 \\
\hline $\mathrm{T}_{4}$ & 8.8 & 8.6 & 7.9 & 7.0 & 6.6 & 6.0 & 5.6 \\
\hline $\mathrm{SE}( \pm$ ) & & 0.05 & 0.17 & 0.71 & 0.07 & 0.21 & 0.06 \\
\hline $\begin{array}{c}\mathrm{CD} \text { at 5\% } \\
\text { level of sig- } \\
\text { nificance }\end{array}$ & & 0.14 & 0.47 & 0.20 & 0.18 & 0.58 & 0.16 \\
\hline
\end{tabular}

${ }^{*}$ Each value is the average of ten observations.

$\mathrm{T}_{0}$ (Control), $\mathrm{T}_{1}(0.2 \%$ sodium benzoate $), \mathrm{T}_{2}(0.2 \% \mathrm{KMS}), \mathrm{T}_{3}(0.2 \%$ potassium sorbet), $T_{4}$ (Combination)

Table 3: Effect of chemical preservatives on organoleptic score for flavor of mango pulp during storage.

\begin{tabular}{|c|c|c|c|c|c|c|c|}
\hline Treatments & \multicolumn{7}{|c|}{ Storage interval (days) } \\
\hline & Fresh & 15 & 30 & 45 & 60 & 75 & 90 \\
\hline $\mathrm{T}_{0}$ & 8.9 & 6.9 & 5.2 & 3.8 & 2.2 & 1.9 & 1.6 \\
\hline $\mathrm{T}_{1}$ & 8.9 & 6.3 & 7.5 & 5.9 & 3.8 & 3.5 & 3.3 \\
\hline $\mathrm{T}_{2}$ & 8.9 & 8.7 & 8.2 & 7.8 & 7.6 & 6.9 & 6.4 \\
\hline $\mathrm{T}_{3}$ & 8.9 & 7.1 & 6.5 & 5.7 & 5.1 & 3.8 & 3.2 \\
\hline $\mathrm{T}_{4}$ & 8.9 & 8.5 & 7.9 & 6.8 & 6.4 & 6.0 & 5.6 \\
\hline $\mathrm{SE}( \pm$ ) & & 0.06 & 0.25 & 0.08 & 0.08 & 0.21 & 0.07 \\
\hline $\begin{array}{c}\mathrm{CD} \text { at 5\% } \\
\text { level of sig- } \\
\text { nificance }\end{array}$ & & 0.17 & 0.69 & 0.23 & 0.21 & 0.58 & 0.19 \\
\hline
\end{tabular}

${ }^{*}$ Each value is the average of ten observations.

$\mathrm{T}_{0}$ (Control), $\mathrm{T}_{1}\left(0.2 \%\right.$ sodium benzoate), $\mathrm{T}_{2}(0.2 \% \mathrm{KMS}), \mathrm{T}_{3}(0.2 \%$ potassium sorbet), $\mathrm{T}_{4}$ (Combination)

Table 4: Effect of chemical preservatives on overall acceptability of mango pulp during storage.

preservatives were significantly decreased from 8.9 to 1.6 during storage. The maximum score was recorded in pulp stored with KMS ( $\left.\mathrm{T}_{2}-6.4\right)$ followed by $\mathrm{T}_{4}$ (Combination), whereas minimum score was recorded in the control sample without addition of any chemical preservatives $\left(\mathrm{T}_{0}-1.6\right)$.

The pulp preserved with potassium meta-bisulphite either alone or in combination with other preservatives and stored in glass bottles retained maximum overall acceptability and negligible microbial count. Statistical analysis showed that storage intervals and treatments had a significant effect on total bacterial count and organoleptic scores for color, flavor and overall acceptability on the mango pulp during storage under the ambient conditions. The results are in conformity with the findings on preservation and storage of mango pulp [8,10-14].

\section{Conclusion}

It can be concluded that addition of $0.2 \%$ potassium meta-bisulphite (KMS) helps in controlling microbial growth and maintaining sensory characteristics of mango pulp packed in glass container and stored for 90 days.

\section{References}

1. Salunkhe DK, Desai BB (1984) Postharvest biotechnology of vegetables. Vol.1 CRC press Inc., Florida, USA.

2. FAOSTAT (2005) FAOSTAT Agricultural data, last updated December 2004 (Agriculture and Food Trade) and July 2005 (Agricultural Production). In FAO, Economic and Social Department, Statistics Division, Statistical Databases of the Food and Agriculture Organization of the United Nations. Internet edition, Rome, Italy.
3. (2007) APEDA, Ministry of Commerce and Industry, Government of India.

4. Giri KV, Krishnamurthy DV, Narashimha Rao PL (1953) Separation of organic acids. J Indian Institute Sci 35A:77-98.

5. Diliello RL (1982) Standard plate count method. Methods in Food and Dairy Microbiology: 20-29.

6. Larmond E (1977) Laboratory methods of sensory evaluation of food Publication 1637, Agriculture Canada, Research Branch, Ottawa.

7. Das MN, Giri NC (1988) Design and Analysis of Experiments (2ndedn), Wiley Eastern Ltd, New Delhi.

8. Hussain S, Rehman S, Randhawa MA, Iqbal M (2003) Studies on physicochemical, microbiological and sensory evaluation of mango pulp storage with chemical preservatives. J Res Sci Home 14: 01-09.

9. Kennedy $L$ (1985) Bobby solar dryers: Their role in post harvest processing Common Wealth Sci Council.

10. Balmeet SG, Navdeep SS, Narpinder S, Maninder S, Davinder S (2004) Effect of $\mathrm{OBrix}$, sodium alginate and drying temperature on colour, texture and sensory properties of 'Dashehari' mango leather. J Food Sci Technol 41: 373-378.

11. Della Modesta RC, Gonçalves EB, Rosenthal A, Silva ALS, Ferreira JCS (2004) Sensory and instrumental evaluation of mango juice. Acta Hortic (ISHS) 645 : 275-277.

12. Saini S, Sogi DS, Bawa AS (2000) Shelf-life studies on chemically preserved sand pear (Pyrus pyrifolia Cv. Patharnakh) pulp. J Food Sci Technol 40: 230232.

13. Karla SK (1982) Preservation of mango (Mangifera indica) pulp. Progressive Hort 14: 205-220.

14. Heikal HA, El-Sidawi MH, El-Wakeil A. (1972) Some factors responsible for the browning of lime and orange juices. Agric Res Rev 50:199-214. 